\title{
Cardiovascular Risk Investigation: When Should It Start?
}

\author{
Anabel Nunes Rodrigues ${ }^{1}$, \\ Gláucia Rodrigues de $\mathrm{Abreu}^{2}$ and Sônia Alves Gouvêa ${ }^{2}$ \\ ${ }^{1}$ School of Medicine, University Center of Espirito Santo, Colatina, \\ ${ }^{2}$ Postgraduate Program in Physiological Sciences, \\ Federal University of Espirito Santo, Vitória, \\ Brazil
}

\section{Introduction}

Childhood can be considered the period of structuring of life, where patterns such as diet and lifestyle are built. Although atherosclerotic disease (AD) becomes symptomatic at a later period of life, early identification and modification of risk factors may further reduce their incidence (Kelishadi et al., 2002). Thus, several studies demonstrate the importance of investigating the presence of risk factors for atherosclerotic disease at this stage as it may result from profound implications for the risk of developing diseases in adulthood (Lenfant \& Savage, 1995; Purath et al., 1995; Gerber \& Zielinsky, 1997; Akerblom et al., 1999).

This chapter presents the main studies that describe the importance of investigating the childhood risk factors for diseases cardiovascular that may emerge in adult life. Thus, the studies involving analysis of cardiovascular risk factors should always register the prevalence and their correlations in childhood, as an essential to identify a population at risk. Thus, beyond the direct benefits on children evaluated such studies could point out other family members carrying from such risks.

Therefore the detection of the risk factors in asymptomatic children can contribute to a decrease in cardiovascular disease, preventing those diseases such as hypertension, obesity and dyslipidemia becomes the epidemic of this new century.

\section{Cardiovascular risk factors}

Atherosclerosis begins early in life. Thus, it is critical to detect cardiovascular disease risk factors during childhood and adolescence in order to prevent future complications. Monitoring these factors helps to identify previous signs that, once modified, can either decrease or even reverse the progression of the dysfunction. Figure 1 shows that a range of risk factors, such as genetic factors, hypertension, dyslipidemia, obesity, metabolic syndrome, atherogenic diet and physical inactivity, are associated with cardiovascular disease. The same figure shows an increase in the prevalence of cardiovascular disease among children and adolescents (Hedley et al., 2004; Eckel et al., 2005; Rodrigues et al., 2006a; Rodrigues et al., 2009). 
Lifestyle and eating habits are risk factors considered to be critical for protection from, the appearance of and the progression of atherosclerotic disease (AD), which is considered the main factor in the genesis of cardiovascular disease (Berlin, 1996, Esrey et al., 1996). For these reasons, a healthy lifestyle and eating habits should be part of heart disease prevention programs (Guedes \& Guedes, 2001). Hypercholesterolemia, hypertriglyceridemia, being overweight, hyperglycemia, hypertension and physical inactivity stand out among these factors (Austin, 1999). Correlation with plasma cholesterol levels and both reductions and delay in the progression of AD through diet and lifestyle changes have been documented (Coelho et al., 1999). Some studies have also suggested that the degree of atherosclerosis in childhood and young adulthood might be correlated with the same risk factors identified in adults. Therefore, an increase in the incidence of cardiovascular disease is likely to occur when today's adolescents enter adulthood. Thus, it is important to either eliminate or reduce risk factors in young people and other age groups (Williams et al., 2002)

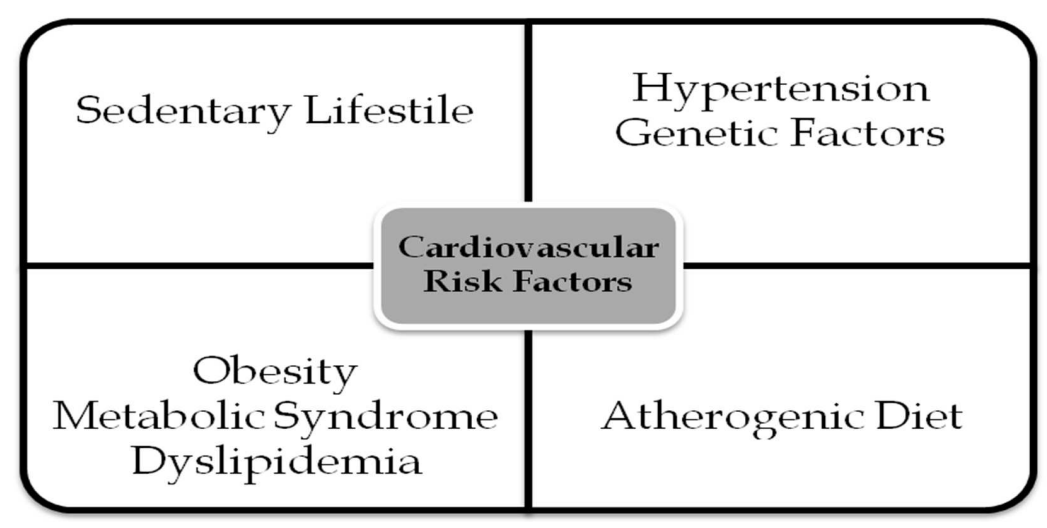

Fig. 1. Factors associated with cardiovascular risk in children and adolescents.

\subsection{Atherosclerosis}

Although AD becomes symptomatic at a later period of life, identifying risk factors early and changing them as soon as possible may further reduce the incidence of AD (Kelishadi et al., 2002). Such diseases currently stand out as the most frequent causes of death. Coronary atherosclerosis is the most evident pathology, and it can affect even young people (Puska, 1986). Studies have suggested that the atherosclerotic process, a disease as old as the human species (Lotufo 1999), begins in childhood. Therefore, its prevention should begin early in life because at this stage, the disease is considered reversible. High levels of lipoproteins present in the blood are critical for the generation of atherosclerosis (Massin et al., 2002). Michaelsen et al. (2002) revealed that children usually do not develop atherosclerosis; however, they develop fatty streaks in the aorta that are reversible. These researchers focused on the fact that a high-fat diet influences blood lipid levels from the first years of life, as do other traditional vascular risk factors.

The variety of criteria for defining optimal lipid levels in adolescence makes it difficult to compare the results in the global literature. However, studies have shown, for example, the presence of atheromatosis in the aortic intima of patients with cholesterol levels between 140 
to $170 \mathrm{mg} \%$. Therefore, the epidemiological goal for children should be, on average, 150 $\mathrm{mg} \%$ for plasma cholesterol (Srinivasan, 1991). In a review of studies conducted in 26 countries (1975 to 1996) involving 60,494 children and adolescents aged 2 to 19 years, Brotons (1998) reported an average of $165 \mathrm{mg} / \mathrm{dL}$ for cholesterol, $60 \mathrm{mg} / \mathrm{dL}$ for HDLcholesterol and $67 \mathrm{mg} / \mathrm{dL}$ for triglycerides.

Studies conducted in Brazil have shown higher levels of cholesterol in adolescents from private schools than in adolescents from public schools (Gerber, 1997; Giuliano, 2005). This trend was corroborated by other studies (Guimarães, 1998 e 2005; Rodrigues et al., 2006a) wherein individuals with lower family income and adolescents from public schools presented lower cholesterol levels than those from higher income families and private schools. These data lead us to agree with the suggestions made by Guimarães (2005) that families with higher socioeconomic status do not necessarily have a better diet or lifestyle. Therefore, children from the lowest income families in developing countries may have less access to the high calories that come from large amounts of saturated fatty acids and a diet with high cholesterol. In addition, students from public schools tend to expend more energy daily because they have to walk to school or walk to get to public transportation.

Regardless of the methodological limitations to calculating LDLc as part of the lipid profile, its determination is widely considered to be the "gold standard" for both risk assessment and for intervention programs for cardiovascular disease (Srinivasan, 2002b). Previous studies by Schrott et al. (1982) and Moll et al. (1983) showed that children and adolescents with elevated LDL-cholesterol often come from families with a high incidence of coronary heart disease. This fact reinforces the importance of LDL-cholesterol determination in adolescence and of autopsy studies performed in children and young people (Newman, 1986), which have indicated that the fatty streaks in the aorta are also directly related to this part of the lipid profile. Thus, by determining the levels of LDLc, it is possible to detect family risks early, and interventions can be implemented before the occurrence of coronary events. It is known that total cholesterol and LDLc can penetrate, produce endothelial injury and stimulate the proliferation of smooth muscle cells, whereas HDL-C is involved in the removal of cholesterol (Reed, 1989). High-density lipoprotein (HDL-cholesterol) carries approximately a quarter of serum cholesterol. Some studies have shown that high levels of HDL-cholesterol are correlated with a lower risk of developing atherosclerosis (Salomen, 1991; Gordon, 1986).

Triglycerides are strongly associated with the risk of developing atherosclerotic disease because they can deposit on the vessel wall and then start the process of low-density lipoprotein accumulation. High levels of triglycerides are a key component of so-called metabolic syndrome (MS). (Johnson, et al. 1999; Santos et al. 2008; Cobayashi et al. 2010).

It is important to emphasize that when dyslipidemia begins in childhood, it tends to remain during growth, and that studies describe a direct relationship between total cholesterol levels in children and cardiovascular disease in adults (Forti, 1996). Studies conducted in Brazil (Rodrigues, 2006; Giuliano \& Caramelli, 2005) have shown that cholesterol levels in childhood may explain $87 \%$ of deaths from cardiovascular disease in adulthood in this country.

The association of inflammatory processes with the development of atherosclerosis provides important links between underlying mechanisms of atherogenesis and risk factors. Several 
studies have examined different circulating markers of inflammations, such as cytokines and adhesion molecules, as potential predictors of the present and the future risk of cardiovascular diseases. Moreover,functional and structural changes are documented in arteries of children with a familial predisposition to atherosclerotic diseases; these changes are associated with clusters of inflammatory factors and markers of oxidation. In addition to the development of atheromatous plaques, inflammation also plays an essential role in the destabilization of artery plaques, and in turn in the occurrence of acute thrombo-embolic disorders. As lifestyle modification trials have been successful in decreasing endothelial dysfunction and the level of markers of inflammation among children and adolescents it is suggested that in addition to expanding pharmacological therapies considered for secondary prevention of atherosclerotic diseases aiming to control the inflammatory process and prevention of atherosclerosis (Kelishadi, 2010).

\subsection{Obesity}

Obesity, which is defined as excessive body fat accumulation, is a heterogeneous disorder with a final common pathway in which energy intake chronically exceeds energy expenditure, and genetic and environmental factors overlap in this disorder (Sorensen, 1995). The energy imbalance frequently begins in childhood, and if it occurs in children that are in the higher percentiles for body fat, it may increase their probability of obesity in adult life. Obesity among youth has increased in recent years (Kelishadi, 2007).

Obesity represents the most common chronic disorder, and it has especially increased prevalence among poor children and minorities (Troiano \& Flegal, 1998). Excessive adiposity in childhood represents a greater risk to the health of an adult than adulthood obesity. The risk of disease in adulthood is greater for overweight children and adolescents than those of normal weight (Gunnell et al., 1998; VanHorn \& Greenland, 1997). Obesity results from a complex interaction of metabolic, physiological, environmental, genetic, social and behavioral factors. The Bogalusa Heart Study, conducted in children and adolescents in Louisiana (USA), showed that obesity, lipoprotein levels (especially LDL) and insulinemia are all significantly correlated with the risk of cardiovascular disease (Srinivasan et al., 1976, Newman et al., 1983, Kikuchi et al., 1992).

Although studies have shown a clear association between severe obesity and increased mortality, there is controversy about the actual damages caused by being overweight. However, its importance as a risk factor for cardiovascular disease is becoming more evident every day (Zanella, 1999). Obesity has received special attention together with two other well-known risk factors: diabetes and hypertension. Therefore, it is important to control obesity during childhood, because obesity acquired in this period of life tends to persist into adulthood (Gerber \& Zielinsky, 1997). Studies have reported a significant increase of overweight children and adolescents in the last decades, which has been associated with an increased risk of hypertension, lipid disorders, type II diabetes, early atherosclerotic lesions and risk of adult obesity and mortality in young adults (Williams et al., 2002; Coronelli \& Moura, 2003, Daniels et al., 2005). Preventing childhood obesity is the best opportunity to make changes in lifestyle and to reduce cardiovascular morbidity and mortality (Buiten \& Metzger, 2000). Diagnosing someone as overweight or obese is difficult because there are questions that remain about the best criteria to be used in order to determine these conditions in this age group. One of the areas of disagreement refers to the 
cutoff for identifying overweight and obese individuals. However, the body mass index (BMI), which is based on international standards, has been useful, inexpensive and reproducible (Giugliano, 2004). Recently, the term obesity has been defined as body mass index $\geq 95$ th percentile in children and adolescents (Daniels, 2005), as shown Table 1.

Statistics on childhood and adolescent obesity worldwide are still limited. A lack of consistency in definitions and age groups studied complicates comparing between prevalences. It is well established that obesity in children and adolescents has increased significantly, including in developing countries (Mello, 2004). Whereas in the United States, obesity affects mainly the social classes with lower purchasing power (Dietz, 1986), in Brazil (for example), the most affected children belong to the wealthiest social classes. Data estimate that childhood obesity affects $16 \%$ of children in Brazil (Giugliano, 2004), and that the prevalence of overweight and obesity is higher in families with higher incomes, (Abrantes, 2002; Moura, 2004). The National Health and Nutrition Examination Survey estimated a prevalence of $30 \%$ for overweight and/or obesity ( $\geq 85$ th percentile) and $15 \%$ for obesity ( $\geq$ 95th percentile) between the ages of 6 and 19 years (O'Brien, 2004).

\subsection{Metabolic syndrome}

Metabolic syndrome (MS) is currently characterized by the combination of a number of risk factors for cardiovascular diseases, including dyslipidemia (hypertriglyceridemia, low HDLc and increased LDLc), high blood pressure, disorders of carbohydrate metabolism and obesity (Reaven, 1988, (Kelishadi, 2007). It has also been demonstrated in children that a direct association between obesity and insulin resistance syndrome is a major precursor of atherosclerotic cardiovascular disease and type II diabetes (Williams et al., 2002).

Although a worldwide consensus on the definition and diagnosis of MS in adults and children does not exist, it is known that MS is associated with a 1.5-fold increase in general mortality and a 2.5-fold increase in cardiovascular mortality (Lakka et al., 2002). Given its importance, many organizations have proposed criteria for the definition and treatment of MS; among them are the World Health Organization (WHO) (Alberti et al., 1998), the National Cholesterol Education Programme Adult Treatment Panel III - NCEP ATP III (NCEP, 2001), European Group for the Study of Insulin Resistance-EGIR (Balkau et al., 1999) and the International Diabetes Federation.

To determine the prevalence of MS in children and adolescents, criteria applied to adults have been modified and used either as pediatric reference values (Cook et al., 2003) or as specific cutoff points (Csabi et al., 2000, Srinivasan et al., 2002). Some studies have suggested that the cutoff points corresponding to the 95th percentile of each variable by gender and age be combined with the height percentile when dealing with blood pressure (NHBPEP, 2004; CDCDM, 1999). However, the lack of consensus results in a markedly different prevalence of this syndrome as reported in many studies (Isomaa et al., 2001, Kelishadi, 2007). Table 1 shows values for lipids, blood pressure and body mass index that characterize children and adolescents that are not considered cardiovascular risk factors.

Prospective studies have shown that obesity appears many years before the onset of insulin resistance (Taskinen, 2003), and insulin resistance is mainly responsible for the hemodynamic and metabolic disturbances of this syndrome (Morton et al., 2001). It is believed that MS is due to a combination of genetic and environmental factors wherein 
obesity plays a primary role, leading to excessive insulin production, which is associated with increased blood pressure and dyslipidemia (Daniels et al, 2005). It is estimated that one million North American adolescents already meet the criteria for MS (Daniels et al., 2005), with a prevalence of $4 \%$ between 12 and 19 years. In addition, MS is present in 30 to $50 \%$ of overweight children (Cook et al., 2003 and Weiss et al., 2004).

\begin{tabular}{|c|c|}
\hline & Acceptable \\
\hline Lipids (mg/dL) & \\
Total Cholesterol & $<150$ \\
LDL-c & $<100$ \\
HDL-c & $\geq 45$ \\
Triglycerides & $<100$ \\
\hline Systolic blood pressure & $<90^{\text {th }}$ Percentile \\
(mmHg) & $\leq 130$ \\
\hline Fasting glucose $(\mathbf{m g} / \mathbf{d L})$ & $\leq 100$ \\
\hline Waist circumference or & $<90^{\text {th }}$ percentile \\
Body mass index $\left(\mathbf{K g} / \mathbf{m}^{2}\right)$ & $<95^{\text {th }}$ percentile \\
\hline
\end{tabular}

Table 1. Reference values proposed for children and adolescents.

\subsection{Hypertension}

Arterial hypertension $(\mathrm{AH})$ has been identified as one of the most potent antecedents of coronary heart disease. It is usually asymptomatic. Prevention is the most efficient way to combat HA, thus avoiding the high social cost of its treatment and complications. Therefore, it is necessary to identify individuals with high blood pressure and control it. The worldwide prevalence of $\mathrm{AH}$ is extremely variable $(2-13 \%)$, and it is dependent on the methodology employed. In Brazil, for example, it is estimated that the prevalence of hypertension in children and adolescents is $4 \%$ (Ministry of Health, 2006), and it is considered imperative to measure blood pressure starting at age 3. It is known that blood pressure (BP) usually increases with age, and that elevated values in young people are a predictor of AH in adulthood (Williams et al., 2002; Falkner et al., 2008). It is worth noting that increasing $\mathrm{BP}$ with age is not normal physiological behavior.

BP should be understood as a result of environmental influences on the expression of several genes that, in turn, also have their own regulatory genes (Bartosh \& Aronson, 1999; Berenson et al., 1998). Several factors known to be related to BP in adults are also associated with the behavior of $\mathrm{BP}$ in children and adolescents, with an emphasis on sex, age, family history of $\mathrm{AH}$ and the presence of either excess weight or obesity. Although AH contributes to the development of cardiovascular complications per se, its association with multiple risk factors increases the risk of major cardiovascular events even more (Kavey et al., 2003, Chobanian et al., 2003; Lieberman, 2002).

It has been accepted that a diagnosis of $\mathrm{AH}$ is confirmed when the values of systolic blood pressure (SBP) and/or diastolic blood pressure (DBP) are greater or equal to the 95th percentile for sex, age and height percentile plus $5 \mathrm{mmHg}$ on three separate occasions. A 
range called pre-hypertension should be identified and assessed for the purpose of adopting strict preventive measures. BP values $\geq 90$ th percentile and $<95$ th percentile characterize pre-hypertension. According to a recommendation proposed by the JNC 7, values that are included in this range and exceeding the limits of $120 / 80 \mathrm{mmHg}$ should also be considered pre-hypertension for adults (Chobanian et al., 2003).

It is estimated that $30 \%$ of overweight/obese children and adolescents have $\mathrm{AH}$ (Sorof \& Daniels 2002). Thus, the presence of overweight/obesity appears to be one of the most important factors related to $\mathrm{AH}$ in children and adolescents worldwide (Chobanian et al., 2003, Campana et al., 2009; European Society of Hypertension 2003). Several studies have shown that the presence of overweight/obesity is associated positively with the occurrence of pre-hypertension in children and adolescents, and when combined they increase the risk of developing AH in adulthood (JAMA, 1992, Monteiro et al., 2003, Rosa et al., 2006, Srinivasan et al., 2006). There are also factors associated predominantly with arterial hypertension in adolescence such as smoking, contraception and drugs: cocaine, amphetamines, alcohol, anabolic steroids, phenylpropanolamine and pseudoephedrine (nasal decongestants).

Thus, changes in lifestyle such as weight control, reducing sodium intake and physical exercise are crucial to preventing hypertension. Although the threshold for blood pressure is not yet well defined, its effects on target organs probably occur in children as well as in adults. Dietary intervention, weight monitoring and regular physical activity should be encouraged at this stage as a primary prevention method (Massin et al., 2002). Studying the stiffness of large arteries, a condition attributed to the aging of blood vessels, Rodrigues et al. (2011) demonstrated that chronic hypotension is the only factor studied able to explain why blood vessel aging did not occur in the study group. In addition to the disturbing reality of the existence of old risk factors in a young population, the presence of these factors not only in isolation, but also in association, has been acknowledged.

\subsection{Sedentary lifestyle}

It has been shown that the mortality rate for cardiovascular disease is lower in individuals who exercise regularly and that the quality of life achieved through a physical fitness program is unquestionably superior. However, this improvement in quality of life depends on a proper exercise prescription wherein the intensity, duration and modality are key elements in achieving a satisfactory outcome. Prescribing physical activities that are performed between the ventilatory threshold and the respiratory compensation point for adults is recommended to obtain beneficial effects on cardiopulmonary capacity (Rondon et al., 1998).

In children, the beneficial effects associated with physical activity include weight control; reductions in cholesterol, insulin resistance and low blood pressure; psychological wellbeing; and an increased predisposition to perform physical activities as a young adult (Williams, et al., 2002).

A major challenge for public health authorities has been to increase the cardiorespiratory capacity of the population. Therefore, childhood and adolescence seem to be the optimal periods for promoting good exercise habits and preventing sedentary behavior in adulthood, which turns preventing cardiovascular disease into a pediatric challenge (Massin 
et al., 2002). In recent decades, children have become less physically active, with a decrease of $600 \mathrm{kcal} /$ day of energy expenditure when compared to children 50 years ago (Boreham \& Riddoch, 2001). Physical inactivity is recognized as an important determinant of chronic diseases, and an increase in its prevalence during childhood has been reported (Twisk, 2001).

Alerts have been issued about the need for physical education programs in schools and for community recreation centers. However, few empirical studies have been conducted to assess the impacts of such facilities and programs on the levels of physical activity and inactivity in adolescents (Gordon-Larsen et al., 2000).

Freedman et al. (1997) report that a sedentary lifestyle is a growing problem; there is a tendency among adolescents to be less engaged in physical activities offered by schools and other vigorous activities, and they spend more time watching television. These behavioral changes may impact future health problems. On the other hand, better physical fitness has been related to a lower risk of cardiovascular compromise in children and adolescents (AlHazaa, 2002) and lower levels of blood pressure in both boys and girls (Fraser et al., 1983, Hofman et al., 1987, Gutin et al., 1990, Hansen et al., 1989, Shears et al., 1986)

It is known that identifying maximal oxygen uptake values (VO2max) supports studies performed attempting to correlate physical aptitude with cardiovascular risk. It is also important to note that $\mathrm{VO}_{2 \max }$ is used to guide exercise prescription and to analyze the effects of training programs (Obert et al., 2003, Armstrong et al., 1994). The aerobic capacity measured by $\mathrm{VO}_{2 \max }$ depends on cardiovascular, respiratory and hematological components and on oxidative mechanisms of muscles during physical activity. It is measured by cardiopulmonary exercise testing, which allows the functions of the cardiovascular and respiratory systems (for instance, gas exchange) to be evaluated simultaneously, (Armstrong et al., 1994). Gas exchange measurements are important to help reveal mechanisms that restrict exercise, because physical activity requires an integrated cardiopulmonary response to compensate for the increase in the metabolic needs of muscle. The fact that cardiorespiratory capacity has been determined by different methods (directly versus indirectly) may explain the variable predictive power of this important physiological variable, and it may also explain the fact that several studies have found that cardiorespiratory capacity is not an independent predictor of blood lipids in children (Tolfrey, 1999).

Adolescence is a period of transition to adulthood in which there are many structural, hormonal, physiological and biochemical changes. Many of these changes interfere with maximum oxygen consumption (Tourinho Filho et al., 1998). Thus, it is necessary to establish $\mathrm{VO}_{2 \max }$ values for each age group. The international literature presents reference values for healthy children and adolescents (Armstrong et al., 1994, Turley et al., 1997; Stanganelli et al., 1991; Rodrigues et al., 2006b).

Described as a behavior, physical activity includes any type of muscle activity in which there is a significant increase in energy expenditure. Physical aptitude is described as a quality, and it usually refers to the ability to perform physical work. It is considered to be an adaptive state and it is (to some extent) genetically determined (Thomas, 2003). It has been suggested that physical aptitude testing should be performed instead of physical activity due to its greater objectivity and reduced possibility of errors. Furthermore, aerobic fitness 
has been shown to correlate better with cardiovascular disease, which is not true for physical activity. Thus, efforts should be intensified to identify the starting point for daily physical activity to elevate the physical aptitude of young people (Bouchard, 1992; McMurray, 1998; Thomas, 2003). However, the assessment of this variable is not yet a global reality, and empirical evaluations have been performed. The use of cardiopulmonary exercise testing enables cardiorespiratory and metabolic capacity to be precisely determined by direct measurement of maximum oxygen consumption $\left(\mathrm{VO}_{2 \mathrm{max}}\right)$, which is the most important physiological measure for the definition of aerobic capacity. It also accurately determines physical aptitude level and thus the correct exercise intensity such that a fitness program will only have healthy consequences (Rondon et al., 1998; Rodrigues, 2006).

\section{Conclusion}

Although the manifestations of coronary heart disease occur in adulthood, detecting risk factors during childhood/adolescence is crucial for establishing a prognosis and preventing target organ damage in adults. Thus, initiating disease detection and prevention at this stage of life and introducing changes in lifestyle can reduce the incidence and severity of cardiovascular diseases.

Risk factors are more meaningful when they are integrated. Hence, studies of cardiovascular risk factors in a region, city or country should always report their prevalence and correlations in childhood as a fundamental step toward identifying the population at risk.

The facts reported here highlight a serious public health problem that must be addressed. There is an urgent need to discuss health promotion issues and the prevention of future diseases that result from the risk factors mentioned herein.

Finally, this chapter demonstrates that risk factors for coronary heart disease begin in childhood, and therefore prevention should start early in life. This increases the need for pediatric care in this age group in order to make early diagnoses and offer preventive advice. Dyslipidemia, for example, is the most well known risk factor, and it can be altered by a moderate restriction of fat without compromising the growth or development of children older than 2. Thus, in the future, a major decrease in cardiovascular diseases could be obtained by assessing asymptomatic children and adolescents.

Thus, social awareness is necessary at all levels, as are studies with planned actions and programs for the control of dyslipidemia, obesity, arterial hypertension and physical inactivity in this age group in order to prevent these risk factors from becoming the epidemic of this new century.

\section{Acknowledgment}

This study was supported by a grant from CEPEG-UNESC-ES.

\section{References}

Abrantes, M.M., Lamounier, J.A. \& Colosimo, E.A. (2002). Prevalência de sobrepeso e obesidade em crianças e adolescentes das regiões Sudeste e Nordeste. Journal of Pediatrics, Vol.78, No.4, pp. 335-340. 
Al-Hazaa, H.M. (2002). Physical activity, fitness and fatness among Saudi children and adolescents: implications for cardiovascular health. Saudi Medical Journal, Vol.23, pp. 144-150.

Alberti, K.G. \& Zimmet, P.Z. (1998). Definition, diagnosis and classification of diabetes mellitus and its complications: Part 1. Diagnosis and classification of diabetes mellitus provisional report of a WHO consultation. Diabetic Medicine, Vol.15, pp. 539-553.

Akerblom, H.K., Viikari, J., Raitakari, O.T. \& Uhari, M. (1999). Cardiovascular risk in Young Finns Study: general outline and recent developments. Annals of Medicine, Vol.31, pp. $45-54$.

Armstrong, N. \& Welsman, J.R. (1994). Assessment and interpretation of aerobic fitness in children and adolescents. Exercise and Sport Sciences Reviews, Vol.22, pp. 435-476.

Austin, M.A. (1999). Epidemiology of hypertriglyceridemia and cardiovascular disease. American Journal of Cardiology, Vol.83, No.9, pp. 13-16.

Balkau, B. \& Charles, M.A. (1999). Comment on the provisional report from the WHO consultation. European Group for the Study of Insulin Resistence (EGIR). Diabetic Medicine, Vol.16, pp. 442-443.

Bartosh, S.M. \& Aronson, A.J. (1999). Childhood hypertension: an update on etiology, diagnosis and treatment. Pediatric Clinics of North America, Vol.46, pp.235-252.

Berenson, G.S., Srinivisan S.R., Bao, W., Newman III, W.P., Tracy, R.E. \& Wattigney, W.A. for the Bogalusa Heart Study (1998). Association between multiple cardiovascular risk factors and atherosclerosis in children and young adults. The New England Journal of Medicine, Vol.338, pp. 1650-1656.

Berlin, J.A. \& Colditz, G.A. (1996). A meta-analysis of physical in the prevention of coronary heart disease. American Journal of Epidemiology, Vol.132, pp. 612-628.

Boreham, C. \& Riddoch C. (2001). The physical activity, fitness and health of children. Journal of Sports Sciences , Vol.19, No.12, pp. 915-929.

Bouchard, C., Dionne, F.T., Simoneau, J.A. \& Boulay, M.R. (1992). Genetics of aerobic and anaerobic performances. Exercise and Sport Sciences Reviews, Vol.20, pp. 27-58.

Brotons, C., Ribera, A., Perich, R.M., Abrodos, D., Magana, P., Pablo, S., Terradas, D., Fernadez, F. \& Permanyer, G. (1998). Worldwide distribution of blood lipidis and lipoproteins in childhood and adolescence: a review study. Atherosclerosis, Vol.139, pp. 1-9.

Buiten, C. \& Metzger, B. (2000). Childhood besity and risk of cardiovascular disease: a review of the science. Pediatric Nursing, Vol.26, No.1, pp. 13-18.

Campana, E.M.G., Brandão, A.A., Magalhães, M.E.C., Freitas, E.V., Pozzan, R. \& Brandão, A.P. (2009). Pré-hipertensão em crianças e adolescentes. Revista Brasileira de Hipertensão, Vol.16, No.2, pp. 92-102.

Chobanian, A.V., Bakris, G.L., Black, H.R., Cushman, W.C., Green, L.A., Izzo, J.L.Jr., Jones, D.W., Materson, B.J., Oparil, S., Wright, J.T.Jr. \& Roccella, E.J. (2003). The Seventh Report of the Joint National Committee on Prevention, Detection, Evaluation, and Treatment of High Blood Pressure. The seventh report of the Joint National Committee (JNC 7 Report) JAMA, Vol.289, No.19, pp. 2560-2572.

Cobayashi, F., Oliveira, F.L.C., Escrivão, M.A.M.S., Silveira, D. \& Taddei, J.A.A.C. (2010). Obesity and Cardiovascular Risk Factors in Adolescents Attending Public Schools. Arquivos Brasileiros de Cardiologia, Vol.95, No.2, pp. 200-206. 
Coelho, O.R., Ueti, O.M. \& Almeida, A. (1999). Lípides como Fator de Risco. In: Mion Jr. D, Nobre F, (Eds). Risco Cardiovascular Global. São Paulo: Lemos Editorial, p.45-64.

Cook, S., Weitzman, M., Auinger, P., Nguyen, M. \& Dietz, W.H. (2003). Prevalence of a metabolic syndrome phenotype in adolescents: findings from the third National Health and Nutrition Examination Survey, 1988-1994. Archives of Pediatrics $\mathcal{E}$ Adolescent Medicine, Vol.157, No.8, pp. 821-827.

Coronelli, C.L.S. \& Moura, E.C. (2003). Hipercolesterolemia em escolares e seus fatores de risco. Saúde Pública, Vol.37, No.1, pp. 24-31.

Csabi, G., Torok, K., Jeges S. \& Molnar, D. (2000). Presence of metabolic cardiovascular syndrome in obese children. European Journal of Pediatrics, Vol.159, pp. 91-94.

Daniels, S.R., Arnett, D.K., Eckel, R.H., Gidding, S.S., Hayman, L.L., Kumanyika, S., Robinson, T.N., Scott, B.J., St Jeor, S. \& Williams, C.L. (2005). Overweight in children and adolescents: pathophysiology, consequences, prevention, and treatment. Circulation, Vol.111, No.15, pp. 1999-2012.

Dietz, W.H. (1986). Prevention of childhood obesity. Pediatric Clinics of North, Vol.33, pp. 823-833.

Eckel, R.H., Daniels, S.R., Jacobs, A.K. \& Robertson, R.M. (2005). America's children: a critical time for prevention. Circulation, Vol.111, pp.1866-1868.

Esrey, K.L., Joseph, L. \& Grover, S.A. (1996). Relationship between dietary intake and coronary heart disease mortality: lipid research clinics prevalence follow-up study. Journal of Clinical Epidemiology, Vol.49, pp. 211-216.

European Society of Hypertension. 2003 European Society of Hypertension-European Society of Cardiology guidelines for the management of arterial hypertension. Journal of Hypertension, Vol.21, pp. 1011-1053.

Executive summary of the third report of the National Cholesterol Education Program (NCEP) expert panel on detection, evaluation, and treatment of high blood cholesterol in adults (adult treatment panel III) (2001). JAMA, Vol.285, pp. 2486-2497.

Falkner, B., Gidding, S.S., Portman, R. \& Rosner, B. (2008). Blood pressure variability and classification of prehypertension and hypertension in adolescence. Pediatrics, Vol.122, No.2, pp. 238-242.

Forti, N., Diogo Giannini, S., Diament, J., Issa, J., Fukushima, J., Dal Bó, C. \& Pereira Barretto A.C. (1996). Fatores de risco para aterosclerose em filhos de pacientes com doença coronariana precoce. Arquivos Brasileiros de Cardiologia, Vol.66, No.3, pp. 119-123.

Fraser, G.E, Phillips, R.L. \& Harris, R. (1983). Physical fitness and blood pressure in school children. Circulation, Vol.67, No.2, pp. 405-412.

Freedman, D.S., Srinivasan, S.R., Valdez, R.A., Williamson, D.F. \& Berenson, G.S. (1997). Secular increases in relative weight and adiposity among children over two decades: The Bogalusa Heart Study. Pediatrics, Vol.99, pp. 420-426.

Gerber, Z.R.S. \& Zielinsky, P. (1997). Fatores de Risco de Aterosclerose na infância. Um Estudo Epidemiológico. Arquivos Brasileiros de Cardiologia, Vol.69, No.4, pp. 231-236.

Giugliano, R. \& Melo, A.L.P. (2004). Diagnóstico de sobrepeso e obesidade em escolares: utilização do índice de massa corporal segundo padrão internacional. Journal of Pediatrics, Vol.80, No.2, pp. 129-134.

Giuliano, I.C.B. \& Caramelli, B. (2005). Dislipidemias em Crianças e Adolescentes. Revista da Sociedade de Cardiologia do Estado de São Paulo, Vol.6, pp. 535-543. 
Giuliano, I.C.B., Coutinho, M.S.S.A., Freitas, S.F.T., Pires, M.M.S., Zunino, J.N. \& Ribeiro, R.Q.C. (2005). Lípides sérico em crianças e adolescentes de Florianópolis, SC Estudo Floripa Saudável 2040. Arquivos Brasileiros de Cardiologia, Vol.85, No.2, pp. 85-91.

Gordon, D.J., Knoke, J., Probstfield, J.L., Superko, R. \& Tyroler, H.A. (1986). High-density lipoprotein cholesterol and coronary heart disease in hypercholesterolemic men: the Lipid Research Clinics Coronary Primary Prevention Trial. Circulation, Vol.74, No.6, pp. 1217-1225.

Gordon-Larsen P., McMurray, R.G. \& Popkin, B.M. (2000). Determinants of Adolescent Physical Activity and Inactivity Patterns. Pediatrics, Vol.105, No.6, pp. 1-8.

Guedes, D.P. \& Guedes, J.E.R.P. (2001). Atividade física, aptidão cardiorrespiratória, composição da dieta e fatores de risco predisponentes às doenças cardiovasculares. Arquivos Brasileiros de Cardiologia, Vol.77, No.3, pp. 243-250.

Guimarães, A.C., Lima, A., Mota, E., Lima, J.C., Martinez, T. \& Conti, A.F. (1998).The cholesterol level of a selected brazilian salaried population: biological and socioeconomic influences. CVD Prevention, Vol.1, pp. 306-317.

Guimarães, I.C.B. \& Guimarães, A.C. (2005). Prevalence of cardiovascular risk factors in selected samples of schoolchildren - socioeconomic influence. Preventive Cardiology, Vol.8, pp. 23-28.

Gunnell, D.J., Frankel, S.J., Nanchahal, K., Peters, T.J. \& Davey Smith, G. (1998). Childhood obesity and adult cardiovascular mortality: a 57-y follow- up study based on the boyd orr cohort. American Journal of Clinical Nutrition, Vol.67, No.6, pp. 1111-1118.

Gutin, B., Basch, C., Shea, S., Contento, I., DeLozier, M., Rips, J., Irigoyen, M. \& Zybert, P. (1990). Blood pressure, fitness and fatness in 5- and 6- year-old children. JAMA, Vol.264, No.9, pp. 1123-1127.

Hansen, H.S., Hyldebrandt, N., Froberg, K. \& Nielsen, J.R. (1989). Blood pressure and physical fitness in school children. The Odense School Children Study. Scandinavian Journal of Clinical \& Laboratory Investigation Supplement, Vol.192, pp. 42-46.

Hedley, A.A., Ogden, C.L., Johnson, C.L., Carroll, M.D., Curtin, L.R. \& Flegal, K.M. (2004). Prevalence of overweight and obesity among US children, adolescents, and adults, 1999-2002. JAMA,Vol.291, pp. 2847-2850.

Hofman, A., Walter, H.J., Connelly, P.A. \& Vaughan, R.D. (1987). Blood pressure and physical fitness in children. Hypertension, Vol.9, pp. 188-191.

Isomaa, B., Almgren, P., Tuomi, T., Forsén, B., Lahti, K., Nissén, M., Taskinem, M. \& Groop, L. (2001). Cardiovascular morbidity and mortality associated with the metabolic syndrome. Diabetes Care, Vol.24, No.4, pp. 683-689.

Johnson, W.D., Kroon, J.J.M., Greenway, F.L., Bouchard, C., Ryan, D. \& Katzmarzyk, P.T. (2009). Prevalence of risk factors for metabolic syndrome in adolescents national health and nutrition examination survey (NHANES), 2001-2006. Archives of Pediatrics \& Adolescent Medicine, Vol.163, No.4, pp. 371-377.

Kavey, R.W., Daniels, S.R., Lauer, R.M., Atkins, D.L., Hayman, L.L. \& Taubert, K. (2003). American Heart Association Guidelines for Primary Prevention of Atherosclerotic Cardiovascular Disease Beginning in Childhood. Circulation, Vol.107, pp. 15621566. 
Kelishadi, R. (2010). Inflammation-induced atherosclerosis as a target for prevention of cardiovascular diseases from early life. Open Cardiovascular Medicine Journal, Vol.4, pp. 24-29.

Kelishadi, R. (2007). Childhood overweight, obesity, and the metabolic syndrome in developing countries. Epidemiologic Reviews,Vol.29, pp. 62-76.

Kelishadi, R., Zadegan, N.S., Naderi, G.A., Asgary, S. \& Bashardoust, N. (2002). Atherosclerosis risk factors in children and adolescents with or without family history of premature coronary artery disease. Medical Science Monitor, Vol.8, No.6, pp. 425-429.

Kikuchi, D.A., Srinivasan, S.R., Harsha, D.W., Webber, L.S., Sellers, T.A. \& Berenson, G.S. (1992). Relation of serum lipoprotein lipids and apolipoproteins to obesity in children: the Bogalusa heart study. Preventive Medicine, Vol.21, No.2, pp. 177-190.

Lakka, H.M., Laaksonen, D.E., Lakka, T.A., Niskanen, L.K., Kumpusalo, E., Tuomilehto, J. \& Salonen, J.T. (2002). The metabolic syndrome and total cardiovascular disease mortality in middle-aged men. JAMA, Vol.288, No.21, pp. 709-716.

Lenfant, C. \& Savage, P.J. (1995). The early natural history of atherosclerosis and hypertension in the young: National Institutes of Health perspectives. American Journal of the Medical Sciences, Vol.310, No.1, pp. 3-7.

Lieberman, E. (2002). Hypertension in childhood and adolescence, In: Kaplan, N.M. Clinical Hypertension (Ed.8), 512-526, Baltimore, Williams \& Wilkins, Philadelphia, New York.

Lotufo, P.A. (1999). Novos conceitos sobre uma velha realidade. In: Mion Jr. D, Nobre, F., (Eds), 31-43, Risco Cardiovascular Global, Lemos Editorial, São Paulo.

Massin, M., Coremans, C. \& Palumbo, L. (2002). Preventive cardiology: the role of the pediatrician. Italian Journal of Pediatrics, Vol.28, pp. 98-104.

McMurray, R.G., Ainsworth, B.E., Harrell, J.S., Griggs, T.R. \& Williams, O.D. (1998). Is physical activity or aerobic power more influential at reducing cardiovascular disease risk factors? Medicine $\mathcal{E}$ Science in Sports \& Exercise, Vol.30, No.10, pp. 15211529.

Mello, E.D., Luft, V.C. \& Meyer, F. (2004). Obesidade infantil: como podemos ser eficazes? Journal of Pediatrics, Vol.80, No.3, pp. 173-182.

Michaelsen, K.F., Dyerberg, J., Falk, E., (2002). Children, fat and cardiovascular diseases. Ugeskr Laeger, Vol.164, No.10, pp. 1334-1338.

Ministério da Saúde (2006). Hipertensão arterial sistêmica, sáude da familia. Cadernos de Atenção Básica, No.15, Brasília, Distrito Federal.

Moll, P.P., Sing, C.F., Weidman, W.H., Gordon, H., Ellefson, R.D., Hodgson, P.A. \& Kottke, B.A. (1983). Total cholesterol and lipoproteins in school children: prediction of coronary heart disease in adult relatives. Circulation, Vol.6, pp. 127-134.

Monteiro, C.A., Conde, W.L. \& Castro I.R. (2003). The changing relationship between education and risk of obesity in Brazil: 1975-1997. Cadernos de Saúde Pública, Vol.19, No.1, pp. 67-75.

Morton, N.M., Holmes, M.C., Fiévet, C., Staels, B., Tailleux, A., Mullins, J.J. \& Seckl, J.R. (2001). Improved lipid and lipoprotein profile, hepatic insulin sensitivity and glucose tolerance in 11 beta hydroxyesteroid dehydrogenase type 1 null mice. The Journal of Biological Chemistry, Vol.276, No.44, pp. 41293-41300. 
Moura, A.A., Silva, M.A.M., Ferraz, M.R.M.T. \& Rivera, I.R. (2004). Prevalência de pressão arterial elevada em escolares e adolescentes de Maceió. Jornal de Pediatria, Vol.80, No.1, pp. 35-40.

National High Blood Pressure Education Program Working Group on High Blood Pressure in Children and Adolescents (2004). The Fourth report on the Diagnosis, Evaluation, and treatment of High Blood Pressure in Children and Adolescents. Pediatrics, Vol.114, pp. 555-576.

Newman, W.P., Freedman, D.S., Voors, A.W., Gard, P.D, Srinivasan, S.R., Cresanta, J.L.,Williamson, D., Webber, L.S. \& Berenson, G.S. (1986). Relation of serum lipoprotein levels and systolic blood pressure to early atherosclerosis. New England Journal of Medicine, Vol.314, pp. 138-144.

Obert, P., Mandigouts, S., Notin, S., Vinet, A., N'Guyen, L.D. \& Lecoq, A.M. (2003). Cardiovascular responses to endurance training in children: effect of gender. European Journal of Clinical Investigation, Vol.33, pp. 199-208.

O'Brien, S.H., Holubkoy, R. \& Reis, E.C. (2004). Identification, evaluation, and management of obesity in an academic primary care center. Pediatrics, Vol.114, pp. 154-159.

Puska, P. (1986). Possibilities of a preventive approach to coronary heart disease strating in childhood. Acta paediatrica scandinavica, Vol.318, pp. 229-233.

Purath, J., Lancinger, T. \& Ragheb, C. (1995). Cardiac risk evaluation for elementary school children. Public Health Nursing, Vol.12, pp. 189-195.

Reaven, G.M. (1988). Role of insulin resistance in human disease. Diabetes, Vol.37, pp. 15951607.

Reed, D.M., Strong, J.P., Resch, J. \& Hayashi, T. (1989). Serum Lipids and Lipoproteins as Predictors of Atherosclerosis. An Autopsy Study. Arteriosclerosis, Vol.9, pp. 560-564.

Rodrigues, A.N. (2006). Perfil Cardiorrespiratório e Metabólico de Escolares da Rede Pública do Município de Vitória. Xiii, 112p., Tese de Doutorado, Universidade Federal do Espírito Santo.

Rodrigues, A.N., Moyses, M.R., Bissoli, N.S., Pires, J.G. \& Abreu, G.R. (2006a). Cardiovascular risk factor in a population of Brazilian schoolchildren. Brazilian Journal of Medical and Biological Research, Vol.39, No.12, pp. 1637-1642.

Rodrigues, A.N., Perez, A.J., Carletti L., Bissoli, N.S. \& Abreu, G.R. (2006b). Maximum oxygen uptake in adolescents as measured by cardiopulmonary exercise testing- a classification proposal. Jornal de Pediatria, Vol.82, No.6, pp. 426-430.

Rodrigues, A.N., Perez, A.J., Pires, J.G., Carletti, L., Araújo, M.T., Moyses, M.R., Bissoli, N.S. \& Abreu, G.R. (2009). Cardiovascular risk factors, their associations and presence of metabolic syndrome in adolescents. Jornal de Pediatria, Vol.85, No.1, pp. 55-60.

Rodrigues, A.N., Coelho, L.C., Goncalves, W.L., Gouvea, S.A., Vasconcellos, M.J., Cunha, R.S. \& Abreu, G.R. (2011). Stiffness of the large arteries in individuals with and without Down syndrome. Vascular Health and Risk Management, Vol.7, pp. 375-381.

Rondom, M.U.P.B., Forjaz, C.L.M., Nunes, N., Amaral, S.L., Barretto, A.C.P. \& Negrão, C.E. (1998). Comparação entre a Prescrição de Intensidade de Treinamento Físico Baseada na Avaliação Ergométrica Convencional e na Ergoespirometria. Arquivos Brasileiros de Cardiologia, Vol.70, No.3, pp. 159-166.

Rosa, M.L., Fonseca,V.M., Oigman, G. \& Mesquita, E.T. (2006). Arterial prehypertension and elevated pulse pressure in adolescents: prevalence and associated factors. Arquivos Brasileiros de Cardiologia, Vol.87, No.1, pp. 46-53. 
Salomen, J. (1991). HDL, HDL2 and HDL3, subfractions and the risk of acute myocardial infarction. Circulation, Vol.84, pp.129-139.

Santos, M.G., Pegoraro, M., Sandrini, F. \& Macuco, E.C. (2008). Fatores de Risco no Desenvolvimento da Aterosclerose na Infância e Adolescência. Arquivos Brasileiros de Cardiologia, Vol.90, No.4, pp. 301-308.

Schrott, H.G., Clarke, W.R., Abrahams, P., Wiebe, D.A. \& Lauer, R.M. (1982). Coronary artery disease mortality in relatives of hypertriglyceridemic school children: the Muscatine study. Circulation, Vol.65, pp. 300-305.

Shears, C.S., Burke, G.L., Freedman, D.S. \& Berenson, G.S. (1986). Values of childhood blood pressure measurements and family history in predicting future blood pressure status: results from 8 years of follow-up in the Bogalusa heart study. Pediatrics, Vol.77, pp. 862-869.

Sorensen, T.I.A. (1995). The genetics of obesity. Metabolism, Vol.44, No.3, pp. 4-6.

Sorof, J. \& Daniels, S. (2002). Obesity hypertension: a problem of epidemic proportions. Hypertension, Vol.40, pp. 441-447.

Srinivasan, S.R., Frerichs, R.R., Webber, L.S. \& Berenson, G.S. (1976). Serum lipoprotein profile in children from a biracial community: the Bogalusa Heart Study. Circulation, Vol.54, No.2, pp. 309-318.

Srinivasan, S.R. (1991). Racial (black-white) differences in serum lipoprotein (a)- distribution ant its relation to parental myocardial infarction in children: the Bogalusa Heart Study. Circulation, Vol.84, pp. 160-167.

Srinivasan, S.R., Myers, L. \& Berenson, G.S. (2006). Changes in metabolic syndrome variables since childhood in prehypertensive and hypertensive subjects: the Bogalusa Heart Study. Hypertension, Vol.48, No.1, pp. 33-39.

Srinivasan, S.R., Myers, L. \& Berenson, G.S. (2002). Distribution and correlates of non-highdensity lipoprotein cholesterol in children: the Bogalusa Heart Study. Pediatrics, Vol.110, No.3, pp. 29-32.

Stanganelli, L.C.R. (1991). Mudanças no $\mathrm{VO}_{2}$ máx e limiar anaeróbico em crianças prépúberes ocorridas após treinamento de resistência aeróbia. Festur, Vol.3, No.2, pp. $42-45$.

Taskinen, M.R. (2003). Diabetic dyslipidemia: from basic research to clinical practice. Diabetologia, Vol.46, pp. 733-749.

The Trials of Hypertension Prevention Collaborative Research Group (1992). The effects of nonpharmacologic interventions on blood pressure of persons with high normal levels: results of the trials of hypertension prevention, phase I. JAMA, Vol.267, pp. 1213-1220.

Thomas, N.E., Baker, J.S. \& Davies, B. (2003). Established and recently identified coronary heart disease risk factors in young people: the influence of physical activity and physical fitness. Sports Medicine, Vol.33, No.9, pp. 633-650.

Tolfrey, K., Campbell, I.G. \& Jone, A.M. (1999). Selected predictor variables and the lipidlipoprotein profile of prepubertal girls and boys. Medical Sciences and Sports Exercise, Vol.31, pp. 1550-1557.

Tourinho Filho, H. \& Tourinho, L.S.P.R. (1998). Crianças, adolescentes e atividade física: aspectos maturacionais e funcionais. Revista Paulista de Educação Física, Vol.12, pp.71-84. 
Troiano, R.P. \& Flegal, K.M. (1998). Overweight children and adolescents: descriptions, epidemiology, and demographics. Pediatrics, Vol.101, pp. 497.

Turley, K.R. \& Wilmore, J.H. (1997). Cardiovascular responses to treadmill and cycle ergometer exercise in children and adults. J Appl Physiol Vol.83, No.3, pp. 948-957.

Twisk, J.W. (2001). Physical activity guidelines for children and adolescents: a critical review. Sports Medicine, Vol.31, No.8, pp. 617-627.

VanHorn, L. \& Greenland, P. (1997). Prevention of coronary artery disease is a pediatric problem. JAMA, Vol.278, pp. 1779.

Weiss R., Dziura J., Burgert, T.S., Tamborlane,W.V., Taksali, S.E., Yeckel, C.W., Allen, K., Lopes, M., Savoye, M., Morrison, J., Sherwin, R.S. \& Caprio, S. (2004). Obesity and the metabolic syndrome in children and adolescents. New England Journal of Medicine, Vol.350, pp. 2362-2374.

Williams, C.L., Hayman, L.L., Daniels, S.R., Robinson, T.N., Steinberger, J., Paridon, S. \& Bazzarre, T. (2002). Cardiovascular health in childhood: a statement for health professionals from the committee on atherosclerosis, hypertension, and obesity in the young (AHOY) of the council on cardiovascular disease in the young, American Heart Association. Circulation, Vol.106, pp. 143-160.

Zanella, M.T. (1999). Obesidade. In: Mion Jr. D, Nobre F., (Eds). Risco Cardiovascular Global, São Paulo: Lemos Editorial, p. 103-114. 


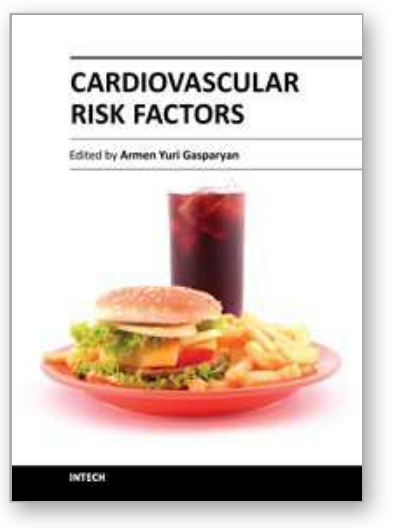

\author{
Cardiovascular Risk Factors \\ Edited by Prof. Armen Gasparyan
}

ISBN 978-953-51-0240-3

Hard cover, 498 pages

Publisher InTech

Published online 14, March, 2012

Published in print edition March, 2012

Cardiovascular risk factors contribute to the development of cardiovascular disease from early life. It is thus crucial to implement preventive strategies addressing the burden of cardiovascular disease as early as possible. A multidisciplinary approach to the risk estimation and prevention of vascular events should be adopted at each level of health care, starting from the setting of perinatology. Recent decades have been marked with major advances in this field, with the emergence of a variety of new inflammatory and immunemediated markers of heightened cardiovascular risk in particular. The current book reflects some of the emerging concepts in cardiovascular pathophysiology and the shifting paradigm of cardiovascular risk estimation. It comprehensively covers primary and secondary preventive measures targeted at different age and gender groups. Attention is paid to inflammatory and metabolic markers of vascular damage and to the assessment of vascular function by noninvasive standardized ultrasound techniques. This is a must-read book for all health professionals and researchers tackling the issue of cardiovascular burden at individual and community level. It can also serve as a didactic source for postgraduate medical students.

\title{
How to reference
}

In order to correctly reference this scholarly work, feel free to copy and paste the following:

Anabel Nunes Rodrigues, Gláucia Rodrigues de Abreu and Sônia Alves Gouvêa (2012). Cardiovascular Risk Investigation: When Should It Start?, Cardiovascular Risk Factors, Prof. Armen Gasparyan (Ed.), ISBN: 978953-51-0240-3, InTech, Available from: http://www.intechopen.com/books/cardiovascular-riskfactors/cardiovascular-risk-investigation-when-should-it-start-

\section{INTECH}

open science | open minds

\section{InTech Europe}

University Campus STeP Ri

Slavka Krautzeka 83/A

51000 Rijeka, Croatia

Phone: +385 (51) 770447

Fax: +385 (51) 686166

www.intechopen.com

\section{InTech China}

Unit 405, Office Block, Hotel Equatorial Shanghai

No.65, Yan An Road (West), Shanghai, 200040, China 中国上海市延安西路65号上海国际贵都大饭店办公楼 405 单元

Phone: +86-21-62489820

Fax: $+86-21-62489821$ 
(C) 2012 The Author(s). Licensee IntechOpen. This is an open access article distributed under the terms of the Creative Commons Attribution 3.0 License, which permits unrestricted use, distribution, and reproduction in any medium, provided the original work is properly cited. 